\title{
Influence of biologic therapy on growth in children with chronic inflammatory connective tissue diseases
}

\author{
Joanna Świdrowska, Agnieszka Zygmunt, Małgorzata Biernacka-Zielińska, Jerzy Stańczyk, \\ Elżbieta Smolewska
}

Department of Pediatric Cardiology and Rheumatology, Medical University of Lodz, Poland

\begin{abstract}
Objectives: Connective tissue diseases (CTD) are a heterogeneous group of chronic inflammatory conditions. One of their complications in children is the inhibition of growth velocity. Due to direct inflammation within the musculoskeletal system as well as glucocorticoid therapy, this feature is the most essential and is mainly expressed in the course of juvenile spondyloarthropathies and juvenile idiopathic arthritis (JIA). Duration of the disease, but predominantly the activity of the inflammatory process, seems to have a significant impact on the abnormal growth profile in children. Effective biological therapy leads to improvement of the patient's clinical condition and also, through the extinction of disease activity and reduction of daily doses of glucocorticosteroids (GCS), it gradually accelerates and normalizes the growth rate in children with CTD. Our objective was to evaluate the impact of biological therapy on growth in children with chronic inflammatory CTD.

Material and methods: Data from 24 patients with CTD treated with tumor necrosis factor- $\alpha$-blockers (etanercept, adalimumab, golimumab) and an interleukin- 6 receptor blocker (tocilizumab) were reviewed at the time of disease onset, biological treatment initiation and at least 12 up to 24 months onwards. The rate of growth was correlated with the daily doses of GCS, and the type and duration of biological therapy.

Results: Patient median height, measured as the change in height standard deviation score, was $0.36 \pm 1.07$ at disease onset and $-0.13 \pm 1.02$ at biologic therapy initiation. The growth velocity accelerated in 17 patients $(70.1 \%)$ during the biological treatment. Mean height-SDS improvement between biological treatment initiation up to two years was $0.51 \pm 0.58$. In $47 \%$ of patients daily doses of GCS were reduced to $0 \mathrm{mg} / \mathrm{kg} /$ day.

Conclusions: In the treatment of CTD, biological agents restore growth velocity not only by inflammation inhibition, but also through limiting GCS daily doses.
\end{abstract}

Key words: biologic treatment, connective tissue diseases, growth impairment, chronic glucocorticosteroid therapy.

\section{Introduction}

Connective tissue diseases (CTD) in children are a heterogeneous group of chronic inflammatory conditions mostly including juvenile idiopathic arthritis (JIA), autoimmune vasculitis, dermatomyositis, and systemic lupus erythematosus. One of their complications is the inhibition of growth velocity [1]. Due to direct inflammation within the musculoskeletal system, this feature is the most essential and is mainly expressed in the course of juvenile spondyloarthropathies and JIA [2]. Duration of the disease, but predominantly the activity of the inflammatory process, seems to have a significant impact on the abnormal growth profile in children [3]. Excessive stimulation of

Address for correspondence:

Joanna Świdrowska, Maria Konopnicka University Hospital No. 4, Sporna 36/50, 91-738 Lodz, Poland, e-mail: j.swidrowska@gazeta.pl Submitted: 28.10.2014, Accepted: 10.02.2015 
pro-inflammatory cytokines, especially interleukin-1 (IL-1), interleukin-6 (IL-6) and tumor necrosis factor $\alpha$ (TNF- $\alpha$ ), causes abnormal secretion of hormones, including growth hormone $(\mathrm{GH})$ and insulin-like growth factor (IGF) [4]. It also causes fluctuations of cortisol concentration in serum. These disorders are significantly worsened by steroids, which are used as a first-line therapy in children with systemic inflammatory CTD [5]. By inhibiting the ongoing inflammatory process, glucocorticosteroids (GCS) improve the general condition of the patient, but used chronically they significantly affect the growth rate through an adverse effect on the hypothalamic-pituitary-adrenal axis (HPAX) [6, 7]. A group of drugs successfully used in the treatment of chronic inflammatory CTD are biological agents [8, 9]. Their mechanisms of action involve inhibition of the activity of pro-inflammatory cytokines: TNF- $\alpha$ (etanercept, adalimumab, golimumab) and IL-6 (tocilizumab). Biological therapy causes rapid remission of the inflammatory process and enables faster reduction of daily doses of GCS. According to reports of recent studies, effective biological therapy not only brings improvement of the patient's clinical condition, but through the extinction of disease activity and reduction of GCS doses it gradually accelerates and normalizes the growth rate in children with chronic inflammatory CTD [10].

\section{Material and methods Patients}

The profile of 24 patients (15 girls, 9 boys) aged 7-21 with chronic inflammatory CTD (polyarteritis nodosa, dermatomyositis, juvenile idiopathic arthritis - polyarticular, oligoarticular and systemic) was retrospectively analyzed. The mean disease duration was 6.5 years (3-17 years). Patients were initially treated with GCS (prednisone at a dose of 0-0.9 mg/kg/day) and selected disease-modifying anti-rheumatic drugs (DMARDs) (methotrexate at a dose of $10-20 \mathrm{mg} / \mathrm{m}^{2}$ body surface area/week; sulfasalazine at a dose of $20 \mathrm{mg} / \mathrm{kg} / \mathrm{day}$, hydroxychloroquine at a dose of $200 \mathrm{mg} /$ day, cyclosporine at a dose of $3 \mathrm{mg} / \mathrm{kg} / \mathrm{day}$, azathioprine at a dose of $2 \mathrm{mg} / \mathrm{kg} /$ day) (Table I). Due to the severe course of disease, refractory to standard treatment, biological therapy was implemented - etanercept subcutaneously at a dose of $0.8 \mathrm{mg} / \mathrm{kg}$ per week (12 patients), adalimumab subcutaneously at a dose of $40 \mathrm{mg}$ per two weeks ( 9 patients, 4 of them after ineffective etanercept treatment), golimumab subcutaneously at a dose of $30 \mathrm{mg} / \mathrm{m}^{2}$ body surface per month ( 2 patients) and tocilizumab intravenously at a dose of 8 or $12 \mathrm{mg} / \mathrm{kg}$ per two weeks or $10 \mathrm{mg} / \mathrm{kg}$ per month (5 patients). Duration of biological therapy was 12-96 months (mean 43.2 months). All patients have never received growth hormone treatment.
All patients were treated with biological agents according to the guidelines of the National Health Fund Therapeutic program. Golimumab was administered under the program of a clinical trial, after obtaining approval from the local bioethics committee.

\section{Growth assessment}

Growth profile was evaluated using standardized Polish growth charts developed by the Institute of Mother and Child in Warsaw (2007). A pediatrician or a registered nurse made the measurements. The height standard deviation score (height SDS; $z$ score), was defined as the observed height minus mean height for age divided by SD, where SD was the standard deviation for the normal population of the same chronological age and gender. Growth rate was evaluated at the time of the disease onset, during the initiation of biological therapy and after at least 12 months up to 2 years of its duration. The rate of growth was correlated with the daily doses of GCS, and the type and duration of biological therapy.

\section{Results}

Median height, expressed as the SD score (SDS), was $0.36 \pm 1.07$ at disease onset, and $0.13 \pm 1.02$ at the time of biological treatment induction. Acceleration of growth velocity was observed in 17 patients (70.1\%) with chronic inflammatory CTD two years after biological therapy initiation. Mean height SDS improvement between biological treatment initiation up to two years of its duration was $0.51 \pm 0.58$ (Fig. 1).

In the group where improvement of the growth profile was seen, 1 patient was treated for system-

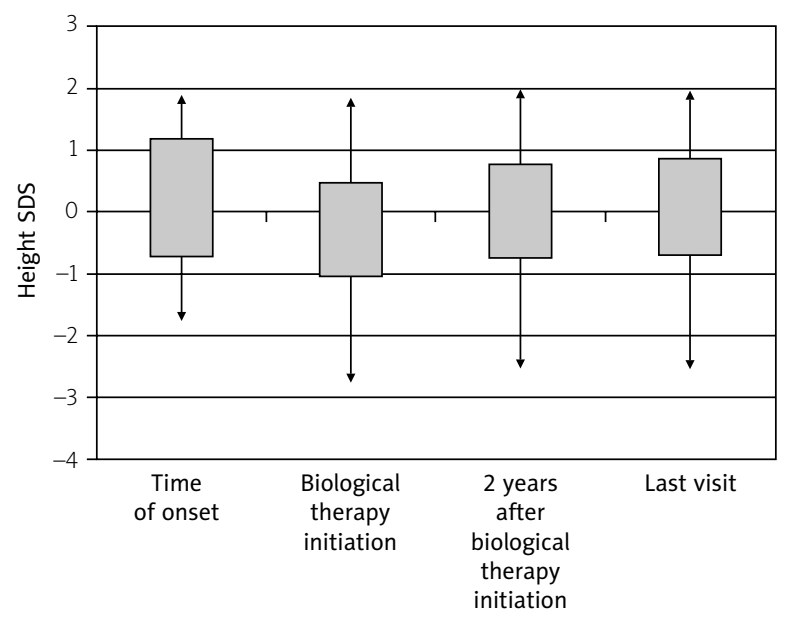

Fig. 1. Height-SDS variations in children with connective tissue diseases treated with biological agents. 
Table I. Patients' characteristics

\begin{tabular}{|c|c|c|c|c|c|c|c|c|}
\hline $\begin{array}{l}\text { Patient } \\
\text { No. }\end{array}$ & $\begin{array}{c}\text { Type of } \\
\text { connective } \\
\text { tissue disease }\end{array}$ & $\begin{array}{c}\text { Age of } \\
\text { onset }\end{array}$ & $\begin{array}{c}\text { Disease } \\
\text { duration } \\
\text { (years) }\end{array}$ & Initial therapy & $\begin{array}{c}\text { Age of } \\
\text { biological } \\
\text { therapy } \\
\text { initiation }\end{array}$ & $\begin{array}{l}\text { Type of } \\
\text { biological } \\
\text { agent }\end{array}$ & $\begin{array}{c}\text { Current } \\
\text { concomitant } \\
\text { therapy }\end{array}$ & $\begin{array}{c}\text { Duration of } \\
\text { biological } \\
\text { therapy } \\
\text { (months) }\end{array}$ \\
\hline 1 & systemic JIA & 3 & 4 & $\begin{array}{c}\text { GCS } \\
0.5 \mathrm{mg} / \mathrm{kg} / \mathrm{day} \\
\text { MTX }\end{array}$ & 5 & tocillizumab & MTX & 24 \\
\hline 2 & systemic JIA & 4 & 10 & $\begin{array}{c}\text { GCS } \\
0.6 \mathrm{mg} / \mathrm{kg} / \text { day } \\
\text { MTX }\end{array}$ & 6 & $\begin{array}{l}\text { etanercept, } \\
\text { adalimumab }\end{array}$ & $\begin{array}{c}\text { GCS } \\
0.06 \mathrm{mg} / \mathrm{kg} / \mathrm{day}, \\
\mathrm{MTX}\end{array}$ & 96 \\
\hline 3 & systemic JIA & 6 & 7 & $\begin{array}{c}\text { GCS } \\
0.4 \text { mg/kg/day, } \\
\text { MTX }\end{array}$ & 10 & tocillizumab & MTX & 39 \\
\hline 4 & polyarticular JIA & 14 & 5 & $\begin{array}{c}\text { GCS } \\
0.5 \mathrm{mg} / \mathrm{kg} / \text { day } \\
\text { MTX }\end{array}$ & 17 & tocillizumab & MTX & 12 \\
\hline 5 & polyarticular JIA & 8 & 10 & $\begin{array}{c}\text { GCS } \\
0.3 \mathrm{mg} / \mathrm{kg} / \mathrm{day} \\
\text { MTX }\end{array}$ & 14 & $\begin{array}{l}\text { etanercept, } \\
\text { adalimumab }\end{array}$ & $\begin{array}{c}\text { GCS } \\
0.05 \text { mg/kg/day, } \\
\text { MTX }\end{array}$ & 56 \\
\hline 6 & polyarticular JIA & 4 & 12 & $\begin{array}{c}\text { GCS } \\
0.6 \text { mg/kg/day, } \\
\text { MTX }\end{array}$ & 12 & adalimumab & $\begin{array}{c}\text { GCS } \\
0.15 \text { mg/kg/day, } \\
\text { MTX }\end{array}$ & 39 \\
\hline 7 & polyarticular JIA & 12 & 4 & $\begin{array}{c}\text { GCS } \\
0.65 \text { mg/kg/day, } \\
\text { MTX }\end{array}$ & 13 & etanercept & MTX & 31 \\
\hline 8 & polyarticular JIA & 10 & 7 & $\begin{array}{c}\text { GCS } \\
0.5 \mathrm{mg} / \mathrm{kg} / \text { day } \\
\text { MTX }\end{array}$ & 14 & $\begin{array}{l}\text { etanercept, } \\
\text { adalimumab }\end{array}$ & $\begin{array}{c}\text { GCS } \\
0.05 \text { mg/kg/day, } \\
\text { MTX }\end{array}$ & 36 \\
\hline 9 & polyarticular JIA & 13 & 3 & sulfasalazine & 13 & adalimumab & sulfasalazine & 39 \\
\hline 10 & polyarticular JIA & 5 & 5 & MTX & 8 & golimumab & MTX & 37 \\
\hline 11 & polyarticular JIA & 5 & 6 & $\begin{array}{c}\text { GCS } \\
0.5 \text { mg/kg/day, } \\
\text { MTX }\end{array}$ & 9 & tocillizumab & MTX & 30 \\
\hline 12 & polyarticular JIA & 7 & 4 & $\begin{array}{c}\text { GCS } \\
0.2 \mathrm{mg} / \mathrm{kg} / \text { day } \\
\text { MTX }\end{array}$ & 5 & golimumab & MTX & 33 \\
\hline 13 & polyarticular JIA & 15 & 3 & sulfasalazine & 15 & tocillizumab & $\begin{array}{c}\text { GCS } \\
0.05 \text { mg/kg/day, } \\
\text { sulfasalazine }\end{array}$ & 34 \\
\hline 14 & oligoarticular JIA & 3 & 9 & $\begin{array}{c}\text { GCS } \\
0.5 \mathrm{mg} / \mathrm{kg} / \mathrm{day}, \\
\text { hydroxychlo- } \\
\text { roquinecyclo- } \\
\text { sporine }\end{array}$ & 5 & etanercept & $\begin{array}{c}\text { GCS } \\
0.25 \text { mg/kg/day, } \\
\text { sulfasalazine, } \\
\text { MTX }\end{array}$ & 70 \\
\hline 15 & oligoarticular JIA & 12 & 6 & $\begin{array}{c}\text { GCS } \\
0.16 \text { mg/kg/day, } \\
\text { MTX }\end{array}$ & 15 & etanercept & MTX & 30 \\
\hline 16 & oligoarticular JIA & 13 & 3 & $\begin{array}{c}\text { GCS } \\
0.5 \mathrm{mg} / \mathrm{kg} / \mathrm{day}, \\
\text { MTX, hydroxy- } \\
\text { chloroquine }\end{array}$ & 14 & etanercept & $\begin{array}{l}\text { MTX, hydroxy- } \\
\text { chloroquine }\end{array}$ & 19 \\
\hline
\end{tabular}


Table I. Cont.

\begin{tabular}{|c|c|c|c|c|c|c|c|c|}
\hline $\begin{array}{l}\text { Patient } \\
\text { No. }\end{array}$ & $\begin{array}{c}\text { Type of } \\
\text { connective } \\
\text { tissue disease }\end{array}$ & $\begin{array}{l}\text { Age of } \\
\text { onset }\end{array}$ & $\begin{array}{c}\text { Disease } \\
\text { duration } \\
\text { (years) }\end{array}$ & Initial therapy & $\begin{array}{l}\text { Age of } \\
\text { biological } \\
\text { therapy } \\
\text { initiation }\end{array}$ & $\begin{array}{l}\text { Type of } \\
\text { biological } \\
\text { agent }\end{array}$ & $\begin{array}{l}\text { Current } \\
\text { concomitant } \\
\text { therapy }\end{array}$ & $\begin{array}{l}\text { Duration of } \\
\text { biological } \\
\text { therapy } \\
\text { (months) }\end{array}$ \\
\hline 17 & oligoarticular JIA & 14 & 4 & $\begin{array}{c}\text { GCS } \\
0.5 \mathrm{mg} / \mathrm{kg} / \text { day, } \\
\text { MTX }\end{array}$ & 15 & $\begin{array}{l}\text { etanercept, } \\
\text { adalimumab }\end{array}$ & $\begin{array}{c}\mathrm{GCS} \\
0.03 \mathrm{mg} / \mathrm{kg} / \text { day }\end{array}$ & 43 \\
\hline 18 & oligoarticular JIA & 3 & 4 & $\begin{array}{c}\text { GCS } \\
0.75 \mathrm{mg} / \mathrm{kg} / \mathrm{day} \\
\text { MTX }\end{array}$ & 4 & etanercept & $\begin{array}{c}\text { GCS } \\
0.15 \mathrm{mg} / \mathrm{kg} / \mathrm{day}, \\
\text { MTX }\end{array}$ & 36 \\
\hline 19 & oligoarticular JIA & 11 & 3 & $\begin{array}{c}\text { GCS } \\
0.4 \mathrm{mg} / \mathrm{kg} / \text { day, } \\
\text { MTX, cyclo- } \\
\text { sporine }\end{array}$ & 12 & etanercept & MTX & 32 \\
\hline 20 & oligoarticular JIA & 7 & 4 & $\begin{array}{c}\text { GCS } \\
0.5 \mathrm{mg} / \mathrm{kg} / \text { day, } \\
\text { MTX }\end{array}$ & 8 & adalimumab & MTX & 43 \\
\hline 21 & oligoarticular JIA & 10 & 3 & $\begin{array}{c}\text { GCS } \\
0.6 \mathrm{mg} / \mathrm{kg} / \mathrm{day}, \\
\text { MTX }\end{array}$ & 10 & adalimumab & MTX & 30 \\
\hline 22 & $\begin{array}{c}\text { polyarteritis } \\
\text { nodosa }\end{array}$ & 8 & 13 & $\begin{array}{c}\text { GCS } \\
0.3 \mathrm{mg} / \mathrm{kg} / \mathrm{day}, \\
\text { azathioprine }\end{array}$ & 14 & etanercept & $\begin{array}{c}\text { GCS } \\
0.125 \mathrm{mg} / \mathrm{kg} / \text { day, } \\
\text { azathioprine }\end{array}$ & 84 \\
\hline 23 & $\begin{array}{l}\text { polyarteritis } \\
\text { nodosa }\end{array}$ & 9 & 12 & $\begin{array}{c}\text { GCS } \\
0.3 \mathrm{mg} / \mathrm{kg} / \text { day, } \\
\text { MTX }\end{array}$ & 13 & etanercept & $\begin{array}{c}\text { GCS } \\
0.05 \mathrm{mg} / \mathrm{kg} / \text { day }\end{array}$ & 84 \\
\hline 24 & dermatomyositis & 3 & 17 & $\begin{array}{c}\mathrm{GCS} \\
0.875 \mathrm{mg} / \mathrm{kg} / \text { day } \\
\text { azathioprine }\end{array}$ & 15 & adalimumab & $\begin{array}{c}\text { GCS } \\
0.15 \mathrm{mg} / \mathrm{kg} / \text { day, } \\
\text { azathioprine }\end{array}$ & 60 \\
\hline
\end{tabular}

GCS - glucocorticosteroids, MTX - methotrexate

ic JIA (33.3\%), 5 patients for oligoarticular JIA (62.5\%), 9 patients for polyarticular JIA (90\%) and 2 patients for polyarteritis nodosa (100\%). The height SDS changes in children with particular diagnoses are shown in Figures 2, 3, 4 and 5 .

Four children (23.5\%) were treated with tocilizumab, 2 children (11.7\%) with golimumab, 5 children (29.4\%) with etanercept, 4 children (23.5\%) with adalimumab, and 2 children (11.7\%) firstly with etanercept and secondly with adalimumab. In $47 \%$ of patients (8 out of 17 with an improved growth rate) daily doses of GCS were reduced to $0 \mathrm{mg} / \mathrm{kg} /$ day. In 2 patients (11.7\%) doses of steroids were minimized to less than $0.05 \mathrm{mg} / \mathrm{kg} /$ day. Unfortunately, in 4 children the GCS therapy was continued at a dose of more than $0.05 \mathrm{mg} / \mathrm{kg} /$ day. Three patients (17.6\%) had never received steroids. At the latest follow-up, the mean height SDS was $-0.03 \pm 1.09$.

In 7 children (29.2\%), despite biological agent administration, the growth velocity did not improve. In that group, 2 patients were treated for systemic JIA (28.5\%), 3 patients for oligoarticular JIA (42.8\%), 1 patients for polyarticular JIA (14.3\%) and 1 patient for dermatomyosi- tis (14.3\%). Three patients were treated with etanercept (42.8\%), 2 patients with etanercept and secondly with adalimumab (28.6\%), 1 patient with tocilizumab (14.3\%), and 1 patient with adalimumab (14.3\%).

In 3 patients the daily dose of GCS was reduced to $0 \mathrm{mg} / \mathrm{kg} /$ day. Four patients were treated with GCS at a mean dose of $0.1 \mathrm{mg} / \mathrm{kg} /$ day $(0.003-0.25 \mathrm{mg} / \mathrm{kg} / \mathrm{day})$.

Between the time of disease onset up to biological therapy initiation 6 children (25\%) had significant growth inhibition (more than 1 height-SDS). All but one patient received GCS at a dose of $0.5 \mathrm{mg} / \mathrm{kg}$ /day or more during that time. After biological treatment induction only 2 of them had only a slight growth rate increase. Significant growth delay was observed in 2 patients (8\%) before the diagnosis of CTD.

\section{Discussion}

There are various factors that may contribute to growth retardation in patients suffering from chronic inflammatory CTD. Disease type and duration, functional joint involvement, age of puberty and severity of the inflammatory process appear to be risk factors for growth impairment 


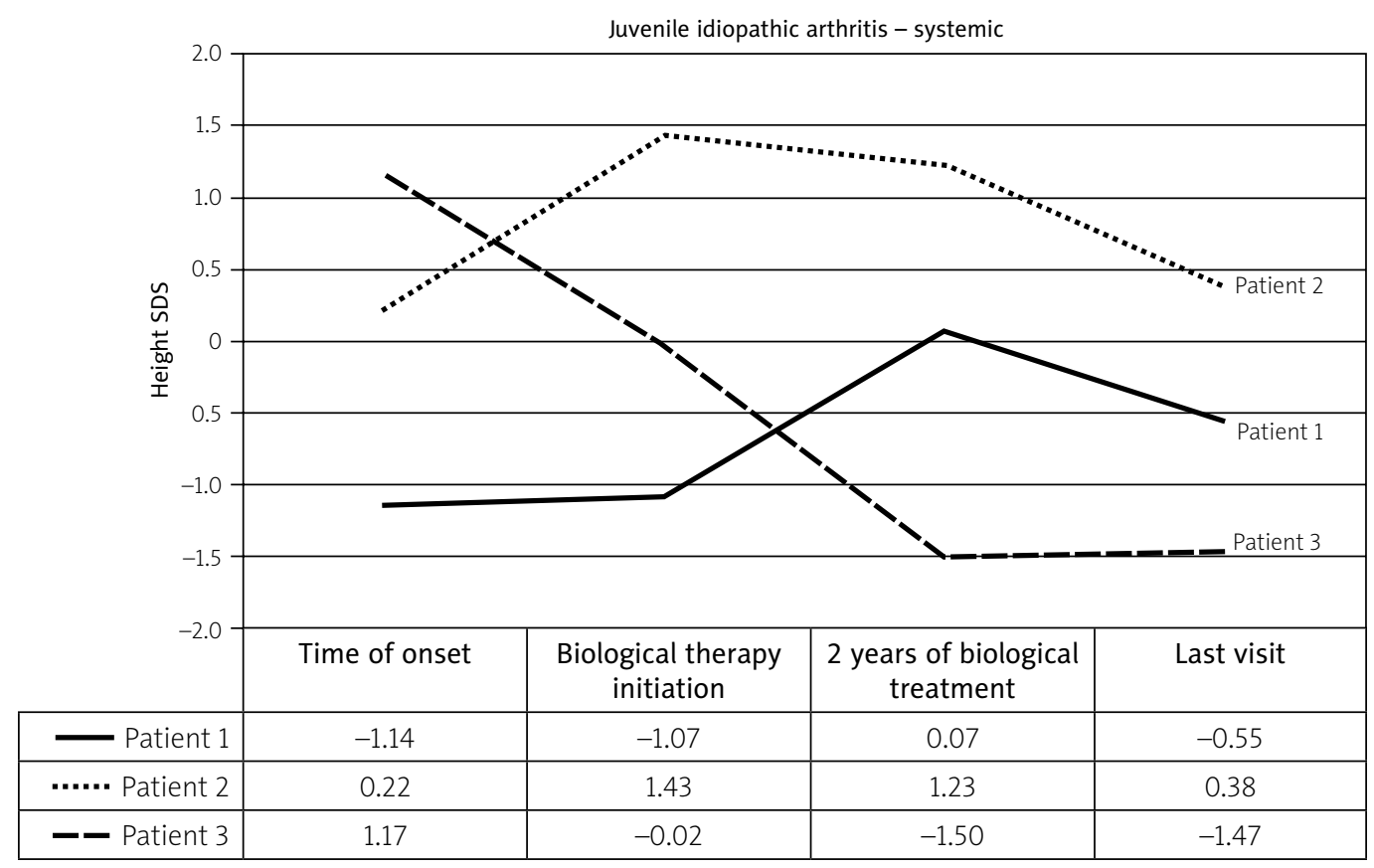

Fig. 2. Height-SDS changes in children with systemic JIA after biological treatment initiation.

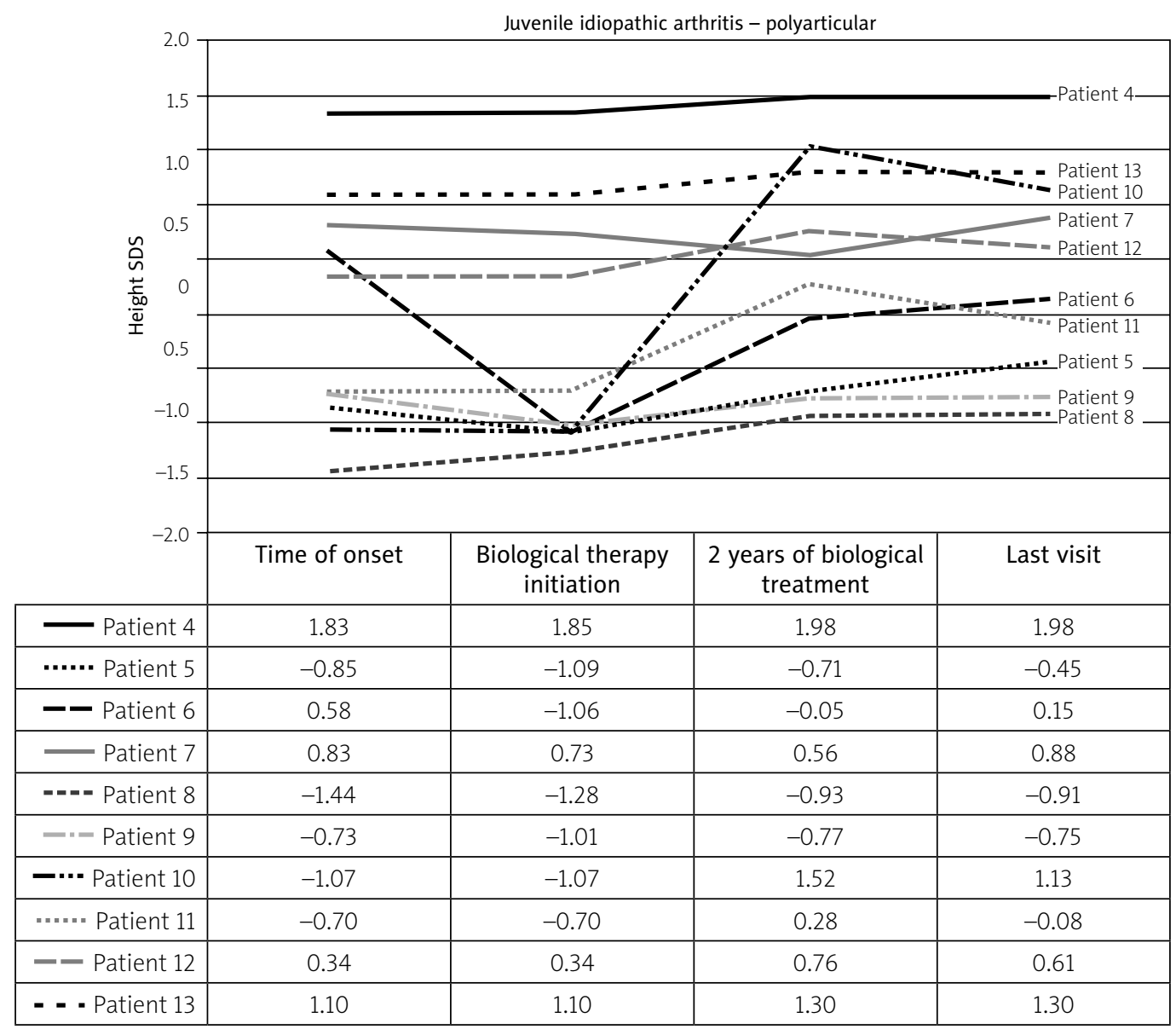

Fig. 3. Height-SDS changes in children with polyarticular JIA after biological treatment initiation. 


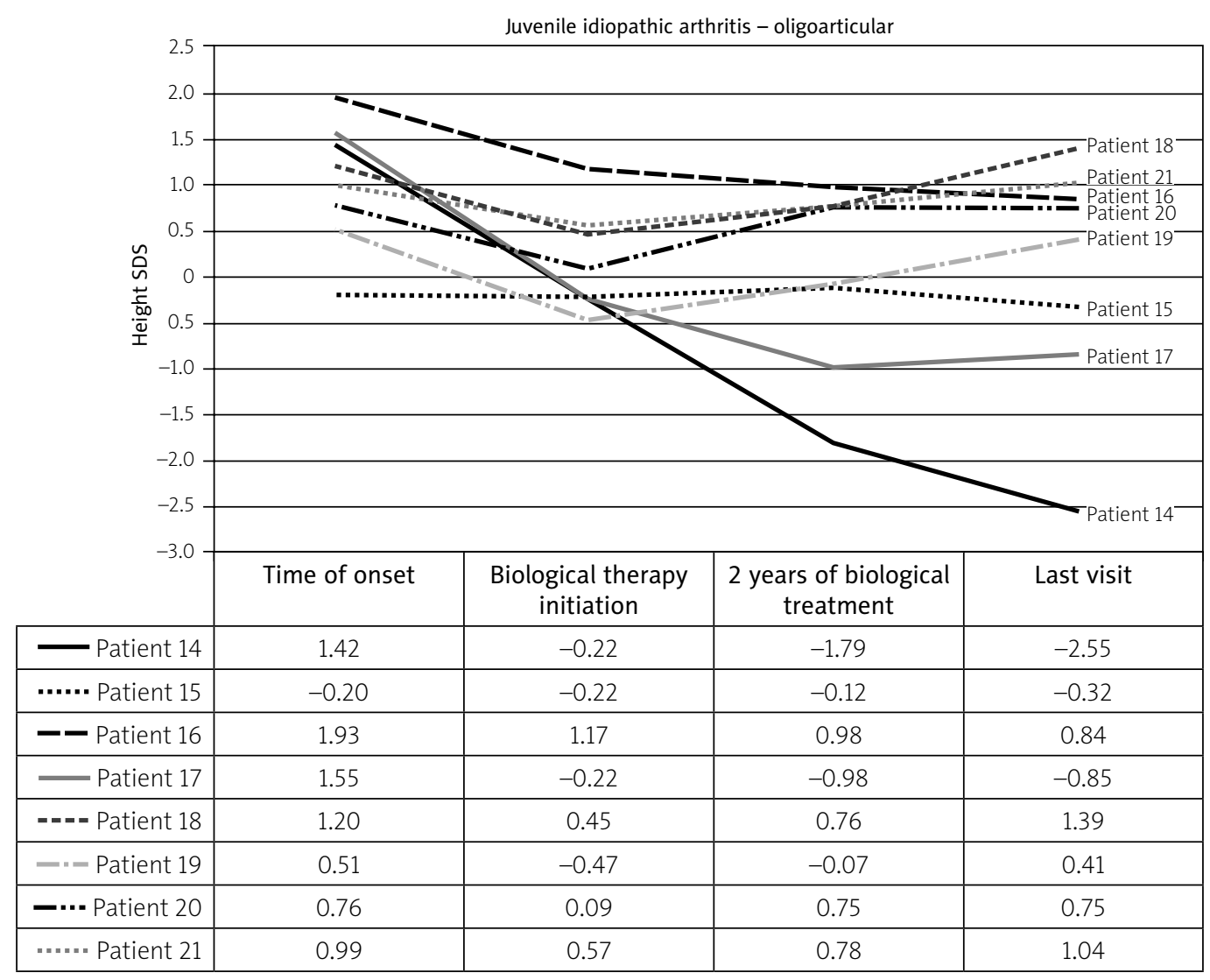

Fig. 4. Height-SDS changes in children with oligoarticular JIA after biological treatment initiation.

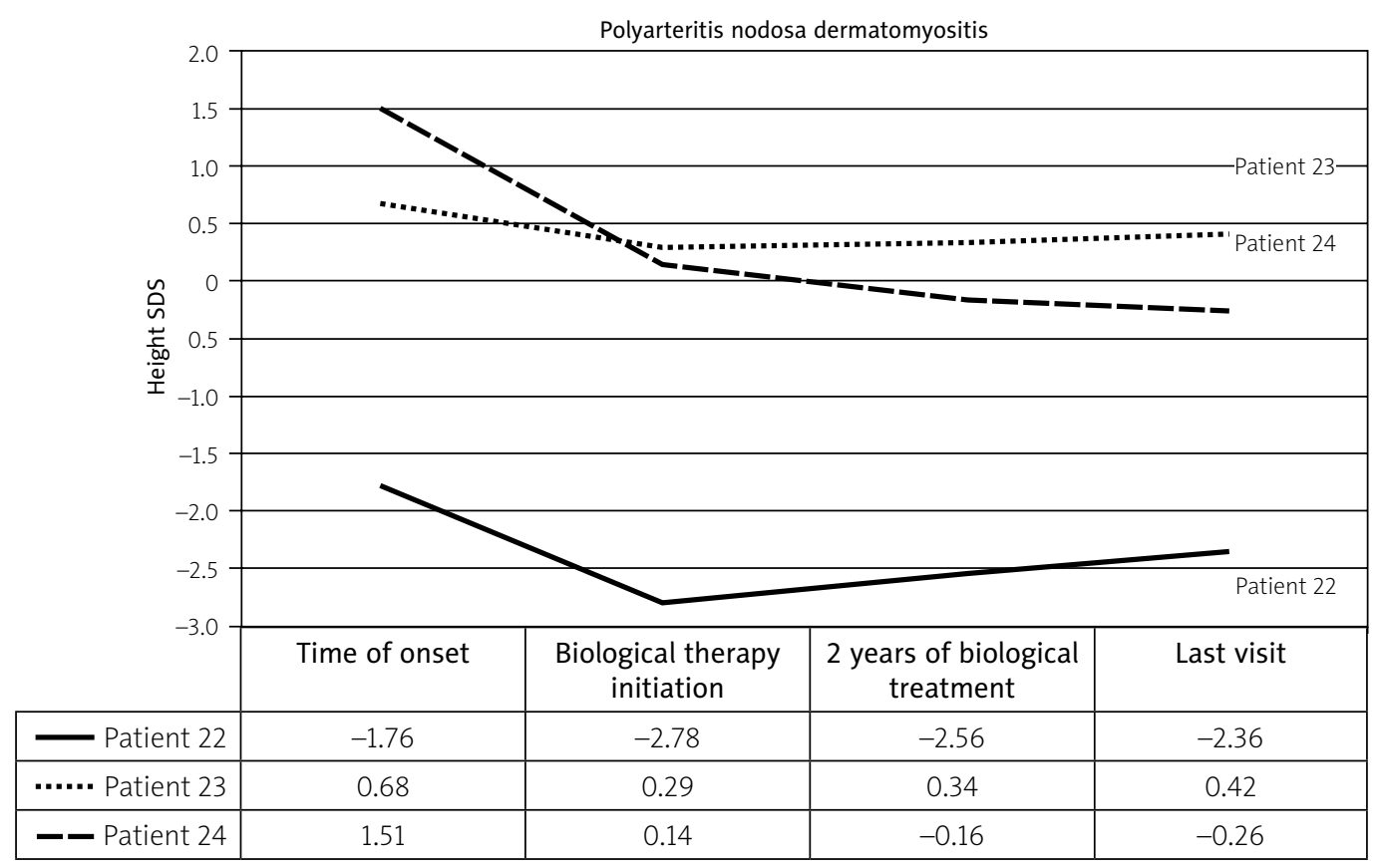

Fig. 5. Height-SDS changes in children with polyarteritis nodosa and dermatomyositis after biological treatment initiation. 
[11]. Glucocorticosteroids, being a first-line therapy, are a frequent cause of deteriorating linear growth in children even if they are administered at low doses [12].

Biological therapy might be effective for both inhibiting the inflammatory process and reducing the daily doses of GCS [13]. By achieving this goal the acceleration of growth velocity might be expected. There are only a few recent studies on the influence of antiTNF $\alpha$ treatment on growth in children with JIA. Giannini et al. [14] reported that even without DMARD therapy, a significant increase in height, weight and BMI in children was observed during long-term etanercept therapy. Moreover, the improvement in growth velocity is the best in patients with the greatest growth retardation. On the other hand, Uettwiller et al. [15] recently found that biologic therapy may be insufficient to restore normal growth velocity. Tynjälä et al. and Schmeling et al. [16] reported that the variation of inflammation activity remains a significant predictor of growth velocity. It simply means that the improvement in growth velocity may be observed due to inflammation inhibition and not by a direct effect of biological agents on growth. It is also proven that there is a significant relation between the variations in GCS doses and the change in growth velocity. The results from our study showed the significant acceleration of growth velocity in children with CTD treated with various biological agents. There were no significant differences between the particular therapies. In around half of the children with growth rate improvement the daily dose of GCS could be reduced to $0 \mathrm{mg} /$ $\mathrm{kg} /$ day or less than $0.05 \mathrm{mg} / \mathrm{kg} /$ day.

\section{Conclusions}

In conclusion, to our best knowledge, this is the first study reporting the impact of biological therapy on growth velocity and GCS consumption not only in JIA, but also in other CTD in children. We have shown that biological drug treatment allows one to control the inflammatory process and also to reduce or withdraw the daily doses of GCS. Normal growth is one of the most important goals in CTD treatment, and biological agents might play a crucial role in achieving it.

The authors declare no conflict of interest.

Financing of the work - the statutory program of the Medical University of Lodz (503/8-000-01/503-01).

\section{References}

1. Polito C, Strano CG, Olivieri AN, et al. Growth retardation in non-steroid treated juvenile rheumatoid arthritis. Scand J Rheumatol 1997; 26: 99-103.
2. Saha MT, Verronen P, Laippala P, Lenko HL. Growth of prepubertal children with juvenile chronic arthritis. Acta Paediatr 1999; 88: 724-728.

3. MacRae VE, Farquharson C, Ahmed SF. The pathophysiology of the growth plate in juvenile idiopathic arthritis. Rheumatology (Oxford) 2006; 45: 11-19.

4. Saha MT, Haapasaari J, Hannula S, et al. Growth hormone is effective in the treatment of severe growth retardation in children with juvenile chronic arthritis. Double blind placebo-controlled followup study. J Rheumatol 2004; 31: 1413-1417.

5. Simon D, Fernando C, Czernichow P, Prieur AM. Linear growth and final height in patients with systemic juvenile idiopathic arthritis treated with longterm glucocorticoids. J Rheumatol 2002; 29: 1296-1300.

6. Falcini F, Taccetti G, Trapani S, et al. Growth retardation in juvenile chronic arthritis patients treated with steroids. Clin Exp Rheumatol 1991; 9: 37-40.

7. Allen DB. Growth suppression by glucocorticoid therapy. Endocrinol Metab Clin North Am 1996; 25: 699-717.

8. Quartier P, Taupin P, Bourdeaut F, et al. Efficacy of etanercept for the treatment of juvenile idiopathic arthritis according to the onset type. Arthritis Rheum 2003; 48: 1093-1101.

9. Imagawa T, Takei S, Umebayashi H, et al. Efficacy, pharmacokinetics, and safety of adalimumab in pediatric patients with juvenile idiopathic arthritis in Japan. Clin Rheumatol 2012; 31: 1713-1721.

10. Miyamae T, Yokota S, Yamanaka H, Yokota S. Effect of tocilizumab on growth impairment in systemic juvenile idiopathic arthritis with long-term corticosteroid therapy. Mod Rheumatol 2014; 24: 567-571.

11. Schmeling H, Seligeri E, Horneff G. Growth reconstitution in juvenile idiopathic arthritis treated with etanercept. Clin Exp Rheumatol 2003; 21: 779-784.

12. Falcini F, Taccetti G, Trapani S, et al. Growth retardation in juvenile chronic arthritis patients treated with steroids. Clin Exp Rheumatol 1991; 9: 37-40.

13. Vojvodich PF, Hansen JB, Andersson U, et al. Etanercept treatment improves longitudinal growth in prepubertal children with juvenile idiopathic arthritis. J Rheumatol 2007; 34: 24812485.

14. Giannini EH, llowite NT, Lovell DJ, et al. Effects of long-term etanercept treatment on growth in children with selected categories of juvenile idiopathic arthritis. Arthritis Rheum 2010; 62: 3259-3264.

15. Uettwiller F, Perlbarg J, Pinto G, et al. Effect of biologic treatments on growth in children with juvenile idiopathic arthritis. J Rheumatol 2014; 41: 128-135.

16. Tynjälä P, Lahdenne $P$, Vähäsalo $P$, et al. Impact of anti-TNF treatment on growth in severe juvenile idiopathic arthritis. Ann Rheum Dis 2006; 65: 1044-1049. 